\title{
Optimization of the Strategy for Recombinant Baculovirus Infection of Suspended Insect Cells
}

\author{
Guohong Zhou ${ }^{1}$, Youhong Zhang ${ }^{2}$ and Yujie Ke ${ }^{2}$ \\ ${ }^{1}$ School of Science, \\ ${ }^{2}$ Key Laboratory for Green Chemical Process of the Ministry of Education, \\ School of Chemical Engineering and Pharmacy, \\ Wuhan Institute of Technology, Wuhan, \\ China
}

\section{Introduction}

\subsection{Significance of baculovirus-insect cell culture system}

The application of baculoviruses for insect pest management is traced back to the 19th century. One of the first reported attempts to use such a virus on an operational scale is the introduction of a multinucleocapsid nucleopolyhedroviruses (MNPV) into the populations of the nun moth, Lymantria monacha in Germany in 1892. Natural agents were used for controlling the insects in ancient China. For expample, pharoah's ants in barns were used to combat destructive insects. Chemical insecticides have been widely used in agriculture due to their strong toxicity to insects. Massive and long term use of chemical insecticides should be avioded because they not only are harmful to human health, but also contaminate water and soil. Viral pesticides are continuously studied and developed and the advantages of using baculoviruses in pest management programs are generally recognized. The important attribute of baculoviruses for pest control is their host-specificity. In most cases, only a few insect species from the same family or the same genus are susceptible to a given virus (Ignoffo, 1968). No member of the baculovirus family has ever been isolated from a host other than an arthropod. In addition, viral insecticides do not create resistance problems in either target or non-target species and they do not show cross-resistance with chemical compounds. A further advantage of using viruses is that they do not create residue problems. They neither accumulate in food chains, nor interact with other pesticide residues. In short, they do not create the problems associated with the use of many chemical insecticides (Primentel et al., 1980). Insect viruses are ideally suited for integration with most other plant protection measures used in integrated pest management (IPM) programs.

In spite of the obvious advantages of viral insecticides over chemical pesticides, the former are scantly used. It has been estimated that baculoviruses are capable of replacing $80 \%$ of the chemical insecticides currently used in agricultural applications. Nevertheless, Helicoverpa armigera single nucleocapsid nucleopolyhedrovirus (HaSNPV) has been adopted for mass production as a viral pesticide and has been widely used to control the insect pests in China (Zhang et al., 1995) and in other countries (Jones, 1994) as well. Since 1993 the first HaSNPV pesticide was registered in China. It is estimated that in the last ten years, the annual output 
of HaSNPV was about 200-300 tons, enough to treat about 100,000 ha of cotton. H. zea single nucleocapsid NPV (HzSNPV) was registered as one of the first commercial baculovirus pesticides (Viron-H, Biocontrol-VHZ, Elcar ${ }^{\mathrm{TM}}$ ) in the 1970s and has been extensively used to control the cotton bollworm in the USA and other countries (Shieh, 1989). HaSNPV has been successfully used to manage heliothine pests, such $\mathrm{H}$. armigera and $\mathrm{H}$. assulta, that are resistant to chemical insecticides and Bt toxin (Zhang, 1989).

The significance of the baculovirus-insect cell culture system has become increasingly evident since many methods have been developed to construct recombinant baculoviruses (Davies, 1994). On this account, there are incentives and advantages for studying this system. Firstly, baculovirus expression systems frequently give high level expression of proteins with full biologicals activity. This combination of highly desirable features is responsible for the widespread popularity of baculovirus expression systems and therefore insect cell cultures offer an attractive for manufacturing of pharmaceuticals, biologicals, etc. Secondly, this system has an additional interest in application of baculoviruses as biological insecticide. Considerable effort has been made to enhance the insecticidal potency of baculoviruses by introducing foreign genes, such as hormones or toxins, to the viral genome (Wood \& Granados, 1991; Bonning \& Hammock, 1992).

Baculoviruses have proven to be an efficient agent for control of insect pests (Bonning \& Hammock, 1992). In addition to this, they can be used efficiently for the production of recombinant proteins by genetic engineering manipulation (Mariorella et al., 1988; Davies, 1994; Kitts, 1996). There is a strong interest in the development of large-scale processes for bio-pesticide production based on the cultivation of insect cells and subsequent infection with baculoviruses. This requires the design and optimization of bioreactors of relatively large volume, and the optimization of their operation strategy. Mathematical modeling has been an important tool in this task (de Gooijer et al., 1989; 1992; Kumar \& Shuler, 1995; Power \& Nielsen, 1996).

\subsection{Bacloviruses}

Baculoviruses comprise a large group of viral pathogens of arthropods, particularly of insects of the orders Lepidoptera, Hymenoptera and Diptera. Over 600 species of insects were susptible to baculoviruses. Viral isolates usually infect only a single or a few related species of insects.

The family Baculoviridae consists of a single genus, Baculovirus, which is divided into two subgroups based on their morphology. Subgroup a viruses, the nucleopolyhedroviruses (NPVs), produce virions which have either a single nucleocapsid per envelope (singlenucleocapsid nuclear polyhedrosis virus, SNPV) or one to many nucleocapsids per envelope (multinucleocapsid nucleopolyhedroviruses, MNPV). Occlusion bodies (OB), i.e. occluded viruses (OVs), called polyhedra due to their crystalline shape appearance in the light microscope, which protect the virions from rapid environmental decay, form in the nucleus of NPV-infected cells. Many enveloped nucleocapsids (virions) are embedded in each OB. Subgroup B viruses, the granulosis viruses (GVs), contain only one nucleocapsid per envelope and asingle virion per OB where it is called Granula (Blissard, 1996). The main characteristic of baculoviruses of both subgroups A and B is that crystalline OBs containing occluded virus particles form in the nuclei of infected cells. The major protein of OBs, called polyhedrin or granulin, accounts for approximately $95 \%$ of the protein of OBs. Baculoviruses from subgroups A and B are large, enveloped viruses with a double-stranded 
circular DNA genome ranging in size from 80 to 200 kilobase pairs (kbp). They are named baculoviruses due to the rod-shaped nucleocapsids.

\subsubsection{In vivo infection and replication of baculoviruses}

The multiplication of baculoviruses in vivo is a complex and highly ordered process. The replication of AgMNPV in midgut epithelial cells is divided into three phases. In phase I (1 to $4 \mathrm{hr}$ p.i.), the infection starts with the food contaminated with occluded viruses and their dissolution in the insect midgut due to the action of the highly alkaline digestive juices $(\mathrm{pH}$ 9.5 to 11.5 ) and possibly some enzymatic degradation also. The released virions are able to penetrate the peritrophic membrane and enter the epithelial cells of the midgut by fusion with the microvillus membrane and are transported into cell nucleus where uncoating of the viral genome occurs. Phase II ( 8 to $12 \mathrm{hr}$ p.i.) represents the replicative stage where virogenic stroma give rise to enveloped nucleocapsids. Other nucleocapsids are released into cytoplasm by means of vesicles originating from the nuclear envelope. In final phase III ((14 to $24 \mathrm{hr}$ p.i.) generally virus-free OBs are produced. In addition, nucleocapsids are released from the vesicles and they acquire an envelope by budding through the plasma membrane and the basal lamina. The budded nonoccluded virus (NOV or BV) possesses a peplomer structure and is responsible for secondary infection within the host insect blood.

The extracellular nonoccluded virus may infect blood cells and other tissues, such as trachea and fat body, where the infection process is repeated. Alternatively, blood cells may invade these tissues and transmit the infection by cell-to-cell contact (Keddie et al., 1989). Early after infection of cells of these tissue, NOVs are produced to vector the infection systemically. Later after infection, NOV production ceases and is followed by the assembly of nucleocapsids in the nucleus into de novo systhesized membranes and occlusion of these virions (OVs) into polyhedra. Nuclei of infected cells from the various tissues become filled with polyhedra. Thus, two infectious froms of the virus (NOVs and OVs), which are phenotypically different but genetically identical, are produced during baculovirus infection.

\subsubsection{In vitro infection and replication of baculoviruses}

The replication of baculoviruses in cell culture (in vitro) is similsr to the events occurring in vivo. However, in contrast to $\mathrm{OV}$, which enters cells by direct fusion at the plasma membrane, NOV (BV) enters cells by endocytosis. After the uptake of the virion into an endocytic vesicle, membrane fusion must occur before releasing the nucleocapsid into the cytoplasm. The nucleocapsids are transported to the nucleus where they are uncoated and the viral DNA is transcribed and replicated. During this period syntheses of host macromoleculars are shut down with concomitant rearrangement of the cytoskeleton, such as disappearance of condensed chromatin. Prgeny DNA is filled into nucleocapsids. At this point, the two viral types begin to emerge in the infection process. Those virions that are destined to become occluded (OVs) remain in the nucleus, and they gain an envelope. In contrast, NOVs escape the nucleus possibly by budding through the inner nuclear membrane and migrate to the plasma membrane (Raghow \& Grace, 1974; Hirumi et al., 1975; Knudson \& Harrap, 1976). By the time they reach the plasma membrane, they are unenveloped nucleocapsids, having lost nuclear membrane remnants in transit. These nucleocapsids bud from plasma membrane into the medium, acquiring an envelope with apikes and resulting in virions composed of single nucleocapsids per envelope. The process 
of budding starts at 10-12 h p.i. and completes around $24 \mathrm{~h}$ p.i., and the NOV production is discontinued after the appearance of polyhedra (Volkman, et al., 1976). The assembled virions are then, in turn, occluded into newly-emerging polyhedra. Finally, the cell and nucleus lyses, releasing the polyhedra that represent about $30 \%$ of the biomass of infected cells and this is the objective of the production of recombinant proteins using this system. In terms of the timing of infection process, the infection cycle of wild-type baculovirus can be divided into three phases: early ( 0 to $6 \mathrm{~h}$ p.i.), late ( 8 to $18 \mathrm{~h}$ p.i.), and very late (20 to $72 \mathrm{~h}$ p.i.) (Miller, 1988). The late phase is characterized by the synthesis of NOVs being capable of budding from the surface. The very late phase is characterized by the embedding of virions in occlusion bodies.

The cytopathic effect that accompanies viral replication is clearly observed with a light microscope. Initial signs of infections in the microscope are a general rounding of the cells, a swelling of the nucleus with a concomitant disappearance of condensed chromatin and the emergence of a defined stippled area, i.e. the virogenic stroma. These signs are evidences to determine which cells are infected when making viral titer of samples.

\subsection{Factors affecting baculovirus-insect cell culture system}

In vitro infection of insect cells with baculoviruses is increasingly considered as a viable means for the production of biopesticides, recombinant veterinary vaccines and other recombinant products (Atkinson et al., 1990). Over the last two decades, much effort has been focused on identifying factors that affect the productivities of such expression systems, including the cell line (Wickham et al., 1995), medium (Caron et al., 1990), oxygen supply (Gotoh et al., 2002), reactor design (Rice et al., 1993; Zhang et al., 1993) and infection strategy, which involves the multiplicity of infection (MOI), time of infection (TOI), initial cell density (ICD) and medium replacement (Carinhas et al., 2009; Hu and Bentley, 2001; Radford et al., 1997; Rodas et al., 2005; Yamaji et al., 1999; Zhang et al., 2005).

Batch processes usually employ intermediate to high MOIs in the exponential phase of growth, which result in synchronous infection of the insect cells and optimal yields of recombinant products or of polyhedra as bioinsecticides (Kumar et al., 1995). A recent study regarding the production of budded viruses (BVs) using a high MOI demonstrated that medium replacement at the time of infection considerably improved BV production, which increased with the cell concentration and reached a virus titer of $2.6 \times 10^{10}$ infectious particles (IPs) per mL in cultures of 3.5 $\times 10^{6}$ Sf9-infected cells per $\mathrm{mL}$ (Carinhas et al., 2009). However, the use of such complex mixtures would involve higher operation costs and lead to variability in the process performance (Carinhas et al., 2009). In the case of high MOIs and higher cell densities, the technology for BV or recombinant protein production becomes more complex. However, the use of a low MOI has been proposed for three major reasons (Enden et al., 2005; Maranga et al., 2003; Wong et al., 1996; Zhang et al., 2005) as follows: (1) at the industrial production scale, the virus inoculum has to come from a certified and costly master bank, and use of a low MOI will increase the lifespan of the master bank; (2) if a low MOI is used, it is not necessary to replace spent medium with virus stock added into the bioreactor, which potentially interferes with the process performance; (3) if a low MOI is used, the problem of the "passage effect" will be minimized. The main consideration for this approach is that inoculation of the viral stock can be carried out directly from a wellcharacterized master bank into a single scaled-up bioreactor. Furthermore, it has been reported that the maximum product titers were lower for a high MOI than for a low MOI after infection in the early exponential growth phase (Hu \& Bentley, 2001; Zhang et al., 
2005). Among all the factors that affect the productivities of insect cell-recombinant baculovirus expression systems, such as the cell line, medium, oxygen supply, bioreactor design and infection strategy involving the MOI, TOI, ICD and medium replacement, the medium, oxygen supply and bioreactor design are relatively fixed for a given expression system, but the infection strategy is relatively uncertain and can be manipulated. More specifically, the interplay among the MOI related to the number of IPs per cell, TOI related to the cell state and cell cycle distribution and ICD affecting the cell concentration at the TOI is of the utmost importance for the design of efficient infection strategies. To date, the relationships among the MOI, TOI and ICD have not been understood at the theoretical level. Quantitatively, orthogonal designs have been widely used to investigate the factors that influence each other in many fields, but the literature related to investigations of the MOI, TOI and ICD for insect cell-recombinant expression systems using orthogonal designs is scarce. To avoid the complexity of the technology associated with large scale productions, high MOIs and medium replacement are not considered to be factors that can be investigated by orthogonal designs. The purpose of the present study was to investigate the quantitative relationships among the TOI, ICD and low MOI and optimize the infection strategy for such expression systems using an orthogonal design.

\section{Materials and methods}

\subsection{Stocks of cells}

Heliothis zea HzAM1 cells were provided by Dr. Hualin Wang from the Wuhan Institute of Virology, Chinese Academy of Sciences (Wang et al., 2008). The cells were maintained at $27^{\circ} \mathrm{C}$ in $25-\mathrm{cm}^{2}$ T-flasks in Grace's medium, comprising Grace's insect medium supplemented with 1\% Yeastolate Ultrafiltrate (Gibco), 1.5\% chemically defined Lipid Concentrate (Gibco) and 5\% fetal bovine serum (Gibco) (unpublished in English). The cells were routinely subcultured every 3-4 days.

\subsection{Cell culture}

HzAM1 cells were inoculated into 100-mL glass Erlenmeyer flasks containing $20 \mathrm{~mL}$ of medium supplemented with $0.2 \%$ Pluronic F-68 (Gibco), and cultured with shaking at 80 rpm. Suspension cultures of HzAM1 cells were collected daily for cell counting in a hemocytometer and cell viability determination by Trypan Blue staining exclusion using a $0.4 \%(\mathrm{w} / \mathrm{v})$ solution (Sigma).

\subsection{Virus stock and bioassay}

A recombinant HaSNPV incorporating the green fluorescent protein (GFP) gene (HaBacHZ8-eGPF-PH) was constructed and kindly provided by Dr. Hualin Wang from the Wuhan Institute of Virology, Chinese Academy of Sciences (Jing et al., 2008; Pan et al., 2007). HzAM1 cells infected with this recombinant virus expressed GFP and were easy to detect under a fluorescence light microscope (BX-51; Olympus) (Cha et al., 1997). For propagation

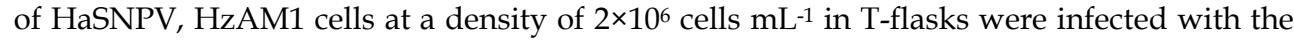
recombinant baculovirus at MOIs of 2-5 and harvested at $72 \mathrm{~h}$ after infection. The infectivity of BVs was measured using the end-point dilution method, and expressed as the $50 \%$ tissue culture infective dose (TCID 50 ) (Nielsen et al., 1992; Reed \& Muench, 1938). The TCID 50 was calculated according to Spearman and Karber (Finney, 1978). Samples were centrifuged at $10,000 \times g$ for $1 \mathrm{~min}$, and the supernatants and cell pellets were stored at $-70^{\circ} \mathrm{C}$ and $4^{\circ} \mathrm{C}$, 
respectively, until analysis. For counts of occluded viruses (OVs), the pellets were treated with an equal volume of $2 \%$ SDS solution for $1 \mathrm{~h}$ at room temperature. Duplicate samples were homogenized and the numbers of OVs or polyhedra were counted in the central square of a hemocytometer under a light microscope (BX-51; Olympus).

\subsection{Experimental protocol}

Shaking cultures were performed in duplicate in $100-\mathrm{mL}$ shake-flasks containing $20 \mathrm{~mL}$ of cell suspension solution with shaking at $80 \mathrm{rpm}$. The temperature was maintained at $27^{\circ} \mathrm{C}$. Controls comprised cell cultures without virus infection. For the HzAM1 cell-recombinant virus system, the MOI, TOI and ICD in the shaking cultures were evaluated using an orthogonal design. The ICD was defined as the cell density when the cells were inoculated into the cultures, and not when the cells were infected. The TOI was defined as the time of infection. The TOIs investigated in the present study were the early, middle and late exponential phases, and the time periods of the cultures differed for different ICDs (Kioukia et al., 1995). The variable assignments and level settings in the orthogonal array design are listed in Table 1. The variable assignments, level settings and experimental arrangements in the orthogonal array design are shown in Tables 2 and 3. A total of nine experiments are

\begin{tabular}{cccc}
\hline \multirow{2}{*}{ Levels } & \multicolumn{3}{c}{ Factors } \\
\cline { 2 - 4 } & MOI & ICD & TOI \\
& $\left(\right.$ TCID $_{\left.50 . \text { cell }^{-1}\right)(\mathrm{A})}$ & $\left(10^{5}\right.$ cells.mL $\left.^{-1}\right)(\mathrm{B})$ & $(\mathrm{h})(\mathrm{C})$ \\
\hline 1 & 0.01 & 1.0 & Early exponential phase \\
2 & 0.1 & 3.0 & Middle exponential phase \\
3 & 1.0 & 2.0 & Late exponential phase \\
\hline
\end{tabular}

Table 1. Variable assignments for the MOI, ICD and TOI and the level settings

\begin{tabular}{|c|c|c|c|c|}
\hline $\begin{array}{l}\text { Experiment } \\
\text { number }\end{array}$ & $\begin{array}{c}\text { MOI } \\
\left(\text { TCID }_{50 \cdot c e l l-1} \text { ) }\right. \\
\text { (A) }\end{array}$ & $\begin{array}{c}\text { ICD } \\
\left(10^{5} \text { cells.mL-1 }\right) \\
\text { (B) }\end{array}$ & $\begin{array}{l}\text { TOI } \\
\text { (h) (C) }\end{array}$ & $\begin{array}{c}\text { Maximum titer } \\
\text { of BV } \\
\left(10^{5} \mathrm{TCID}_{50 .} \mathrm{mL}^{-}\right. \\
1)\end{array}$ \\
\hline 1 & 1 & 1 & 1 & 2.00 \\
\hline 2 & 1 & 2 & 2 & 28.00 \\
\hline 3 & 1 & 3 & 3 & 9.28 \\
\hline 4 & 2 & 1 & 2 & 20.00 \\
\hline 5 & 2 & 2 & 3 & 92.8 \\
\hline 6 & 2 & 3 & 1 & 200.00 \\
\hline 7 & 3 & 1 & 3 & 6.32 \\
\hline 8 & 3 & 2 & 1 & 6.32 \\
\hline 9 & 3 & 3 & 2 & 13.30 \\
\hline$K_{1}\left(10^{5} \mathrm{TCID}_{50} \cdot \mathrm{mL}^{-1}\right)$ & 13.09 & 9.44 & 69.44 & \\
\hline$K_{2}\left(10^{5} \mathrm{TCID}_{50} \cdot \mathrm{mL}^{-1}\right)$ & 104.27 & 42.37 & 20.43 & \\
\hline$K_{3}\left(10^{5} \mathrm{TCID}_{50} \cdot \mathrm{mL}^{-1}\right)$ & 8.65 & 74.19 & 36.13 & \\
\hline $\mathrm{R}\left(10^{5} \mathrm{TCID}_{50} \cdot \mathrm{mL}^{-1}\right)$ & 95.62 & 64.75 & 49.01 & \\
\hline
\end{tabular}

Table 2. Effects of the MOI, ICD and TOI on the BV titer 


\begin{tabular}{|c|c|c|c|c|}
\hline Experiment & $\begin{array}{c}\text { MOI } \\
\left(\text { TCID }_{50 \cdot \text { cell-1) }}\right) \\
(\mathrm{A})\end{array}$ & $\begin{array}{c}\text { ICD } \\
\left(10^{5} \text { cells.mL-1) }\right. \\
\text { (B) }\end{array}$ & $\begin{array}{c}\text { TOI } \\
\text { (h) (C) }\end{array}$ & $\begin{array}{l}\text { Maximum OV } \\
\text { concentration } \\
\left(10^{4} \text { OV.mL-1) }\right.\end{array}$ \\
\hline 1 & 1 & 1 & 1 & 110 \\
\hline 2 & 1 & 2 & 2 & 120 \\
\hline 3 & 1 & 3 & 3 & 125 \\
\hline 4 & 2 & 1 & 2 & 145 \\
\hline 5 & 2 & 2 & 3 & 160 \\
\hline 6 & 2 & 3 & 1 & 190 \\
\hline 7 & 3 & 1 & 3 & 125 \\
\hline 8 & 3 & 2 & 1 & 142 \\
\hline 9 & 3 & 3 & 2 & 160 \\
\hline$K_{1}^{\prime}\left(10^{4} \mathrm{OV}^{\prime} . \mathrm{mL}^{-1}\right)$ & 118 & 127 & 147 & \\
\hline$K_{2}^{\prime}\left(10^{4} \mathrm{OV}^{\prime} \cdot \mathrm{mL}^{-1}\right)$ & 165 & 141 & 142 & \\
\hline$K_{3}^{\prime}\left(10^{4}\right.$ OVs.mL $\left.{ }^{-1}\right)$ & 142 & 158 & 137 & \\
\hline $\mathrm{R}^{\prime}\left(10^{4}\right.$ OVs.mL-1) & 47 & 32 & 11 & \\
\hline
\end{tabular}

Table 3. Effects of the MOI, ICD and TOI on the OV concentration

listed in the trial columns. The numbers 1, 2 and 3 under the various column numbers in the tables represent the level settings in the experiments. The $K_{m}$ or $K_{m}{ }^{\prime}(m=1-3)$ values and the $\mathrm{R}$ or $\mathrm{R}^{\prime}$ values in the last four rows of Tables 2 and 3 are the average responses, i.e., BVs or OVs with variable $m$, and the differences between the maximum and minimum values with variable $m$, respectively. The $K_{m}$ or $K_{m}{ }^{\prime}$ values were used to estimate the effects of the variable and the $R$ or $R^{\prime}$ values were used to evaluate the sensitivity of the variable to the BV titer or OV concentration.

\section{Results}

After implementing the nine experimental trials designed according to the $\mathrm{L}_{9}\left(3^{4}\right)$ orthogonal array shown in Table 2, with sampling for measurements of the BV titer and OV concentration every $12 \mathrm{~h}$ and the cell density every $24 \mathrm{~h}$, the output responses for each experimental trial were calculated (Tables 2 and 3). As shown in the last column of Table 2, the maximum BV titer of $2.00 \times 10^{7} \mathrm{TCID}_{50} \mathrm{~mL}^{-1}$, equivalent to $9.2 \times 10^{9} \mathrm{IPs} \mathrm{mL}^{-1}\left(1 \mathrm{TCID}_{50} \mathrm{~mL}^{-1}\right.$ $=460 \mathrm{IPs} \mathrm{mL}^{-1}$, based on flowcytometry analysis and the end-point dilution method; data not shown), was obtained for the condition of $\mathrm{A}_{2} \mathrm{~B}_{3} \mathrm{C}_{1}$. Furthermore, the optimal conditions for that experiment were also $A_{2} B_{3} C_{1}$, as evaluated by analyzing the $K_{m}$ values, i.e., the average responses at each of the three levels. These results indicated that the optimal conditions for BV production in the suspended HzAM1 cell-recombinant virus system were inoculation of the suspended cells at an ICD of $2.0 \times 10^{5}$ cells mL-1 and a MOI of 0.1 when the cells were at the early exponential growth phase. As shown in the last column of Table 3 , the maximum OV concentration of $1.9 \times 10^{6} \mathrm{OVs} \mathrm{mL}^{-1}$ was obtained for the condition of $\mathrm{A}_{2} \mathrm{~B}_{3} \mathrm{C}_{1}$. Furthermore, the optimal conditions for that experiment were also $A_{2} B_{3} C_{1}$, as evaluated by analyzing the $K_{m}{ }^{\prime}$ values. Consequently, the optimal conditions for OV production were the same as those for BV production in the suspended HzAM1 cell-recombinant virus system. These findings are logically reasonable and indicate that BVs and OVs are closely related, representing only two different virion phenotypes. 
Fig. 1 shows the evolution of the unstained cell concentration for the ICDs of $1.0 \times 10^{5}$, $2.0 \times 10^{5}$ and $3.0 \times 10^{5}$ cells $\mathrm{mL}^{-1}$, and in a control experiment. The data indicated that the maximum unstained cell concentration, decrease in growth rate upon infection, time of onset of a decrease in the unstained cell concentration and the decrease drop rate were dependent on not only the ICDs, but also the TOIs and MOIs (Fig. 1a-c). Since the large change in the BV concentration requires logarithmic presentation of the data and the primary data were obtained as the negative logarithm of the $\operatorname{TCID}_{50}\left[-\log \left(\mathrm{TCID}_{50}\right)\right]$, and the error of the method is estimated in the logarithmic scale and not easily translated into linear units, the evolution of the number of BVs was calculated in the form of $-\log \left(\mathrm{TCID}_{50}\right.$ ) (Zhang et al., 2005). Fig. 2 shows the evolution of the $-\log \left(\mathrm{TCID}_{50}\right)$ for the ICDs of $1.0 \times 10^{5}, 2.0 \times 10^{5}$ and $3.0 \times 10^{5}$ cells $\mathrm{mL}^{-1}$. The errors of all the sample analyses ranged from $0 \%$ to $5 \%$ and are not indicated in Fig. 2. The maximum value of the $-\log \left(\mathrm{TCID}_{50}\right)$ was 6.0 (Fig. $2 \mathrm{~b}$, compare with Fig. $2 \mathrm{a}$ and $\mathrm{c}$ ) and the corresponding BV value was $2.0 \times 10^{7} \mathrm{TCID}_{50} \mathrm{~mL}^{-1}$ in the case of an ICD of $2.0 \times 10^{5}$ cells $\mathrm{mL}^{-1}$, a MOI of 0.10 and a TOI at the early exponential phase. These represent the best results obtained for the HzAM1 cell-recombinant baculovirus system, based on comparisons with previously reported data (McIntosh et al., 2001; Wang et al., 2008). Fig. 3 shows the evolution of the amount of OVs for the ICDs of $1.0 \times 10^{5}, 2.0 \times 10^{5}$ and $3.0 \times 10^{5}$ cells $\mathrm{mL}^{-1}$. The errors of all the sample analyses ranged from $0 \%$ to $5 \%$ and are not indicated in Fig. 3. The maximum OV concentration of $1.9 \times 10^{6} \mathrm{OVs} \mathrm{mL}^{-1}$ compared with those in Fig. 3a and $\mathrm{c}$ was obtained for an ICD of $2.0 \times 10^{5}$ cells $\mathrm{mL}^{-1}$, a MOI of 0.10 and a TOI at the early exponential phase.

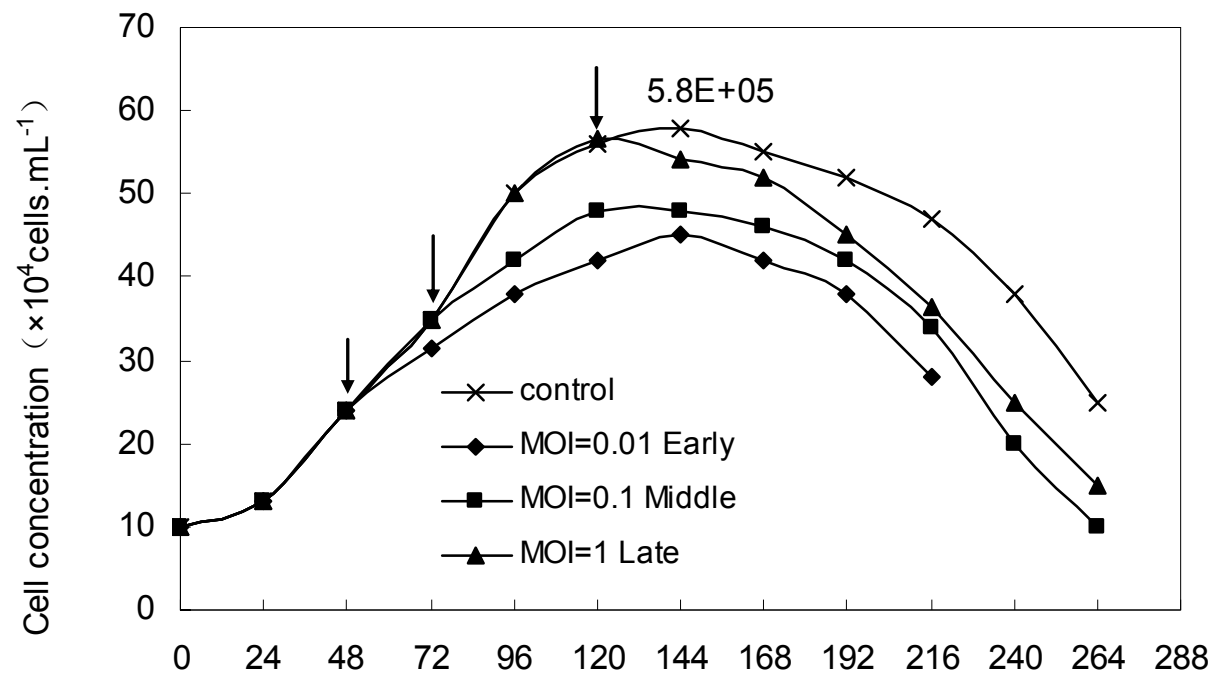

Time (h)

(a) 


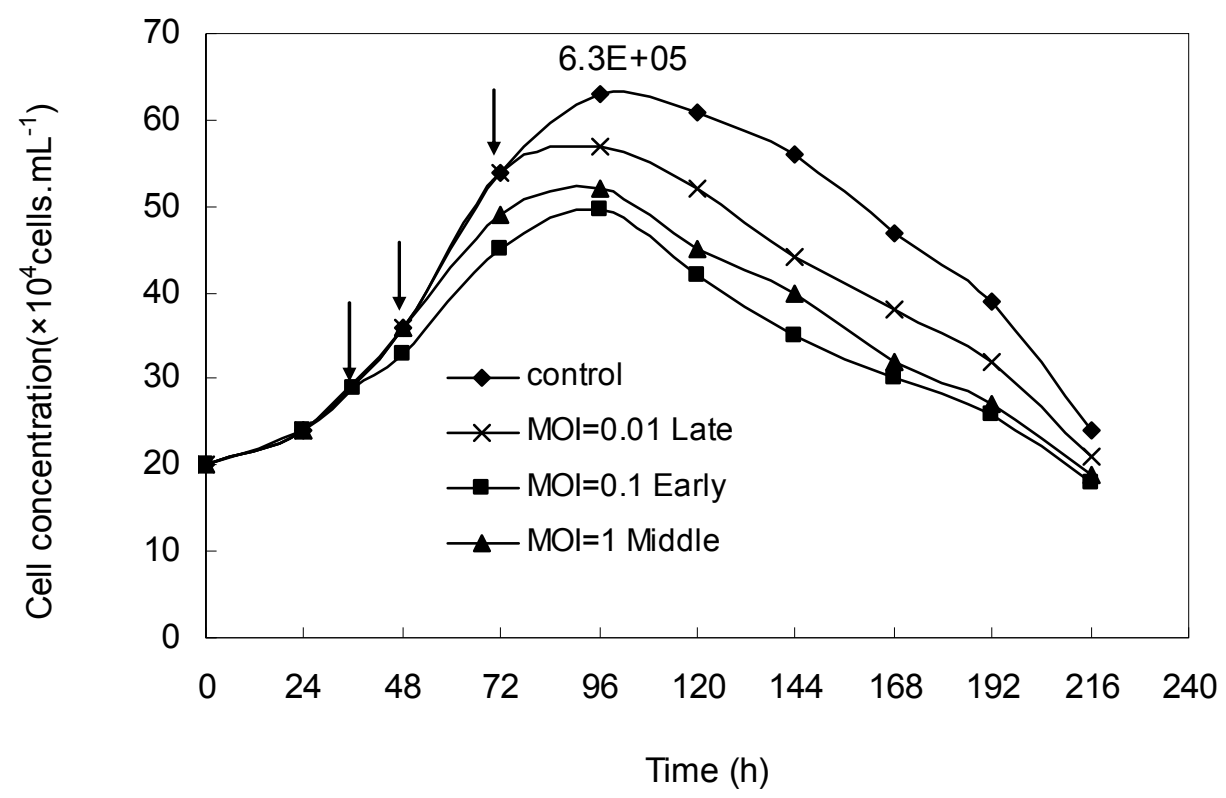

(b)

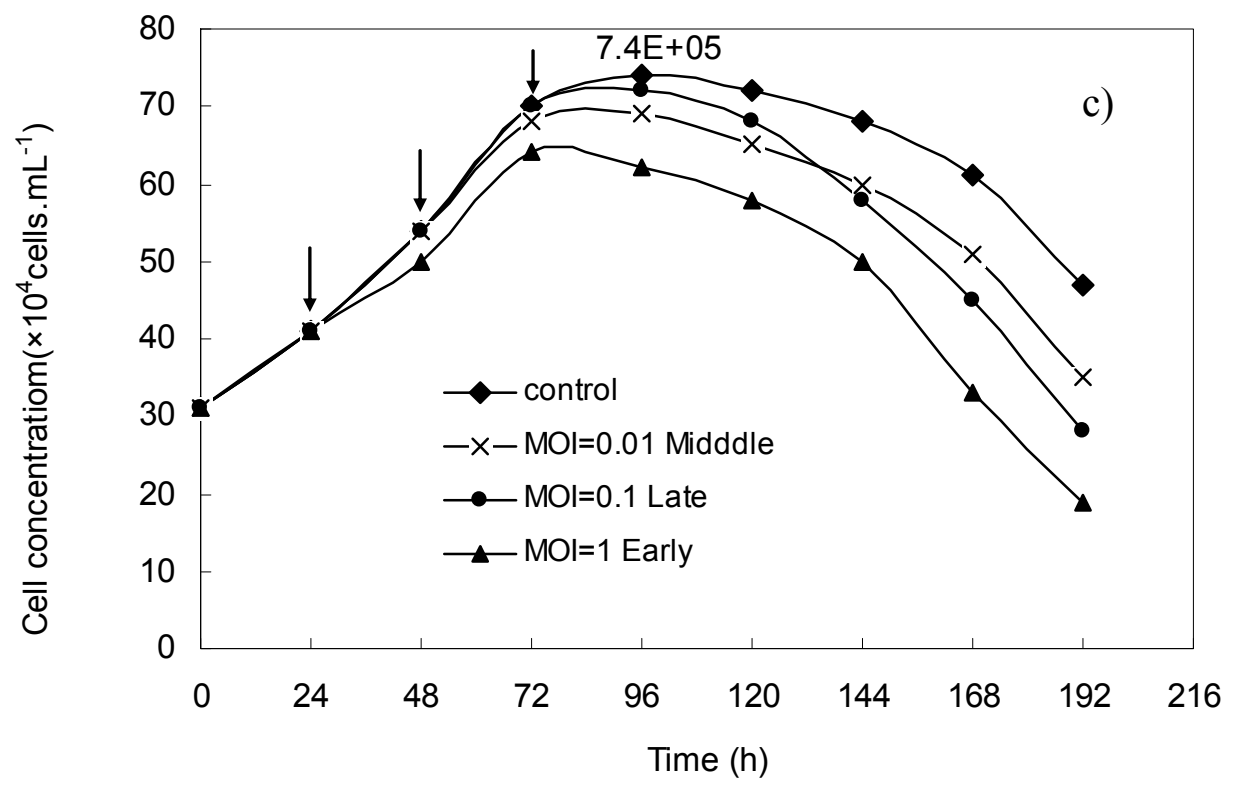

(c)

Fig. 1. Evolution of the unstained cell concentration for the ICDs of $1.0 \times 10^{5}$ cells mL-1 (a), $2.0 \times 10^{5}$ cells mL-1 (b) and $3.0 \times 10^{5}$ cells mL-1 (c) and in a control experiment. Arrows indicate the times when the viruses were added to the cultures. 


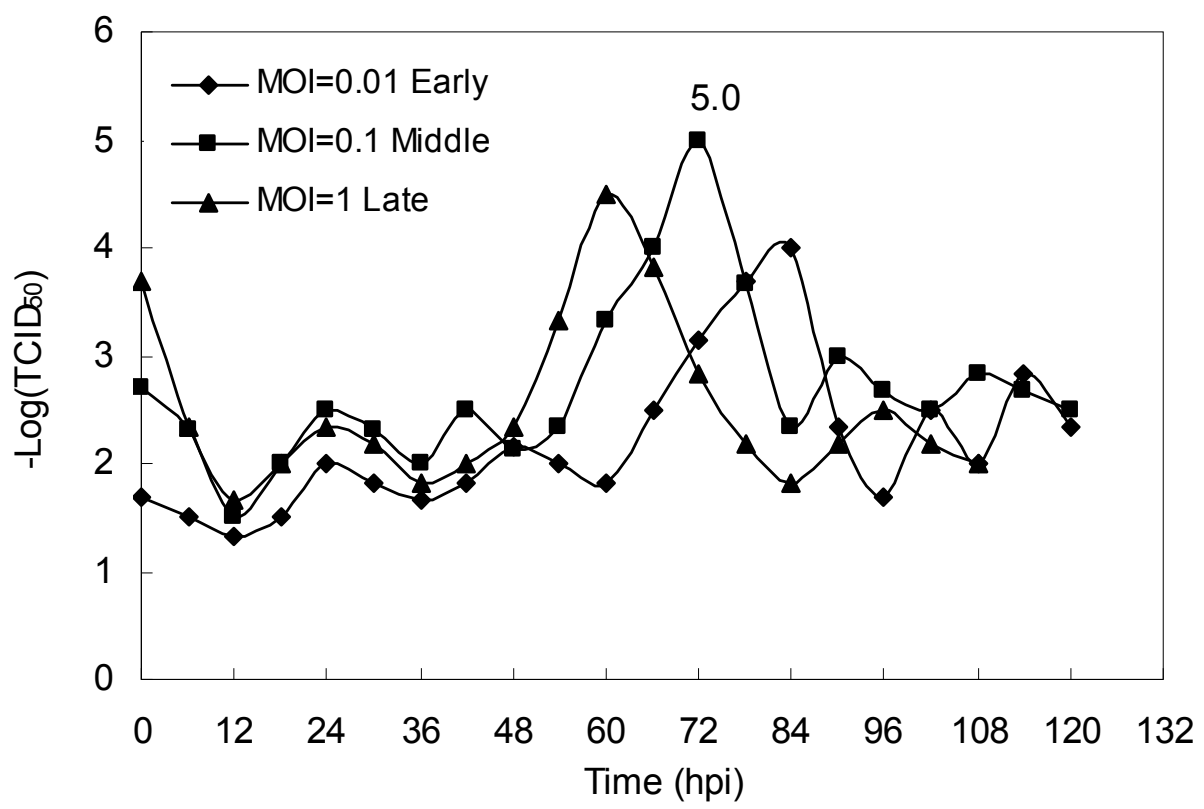

(a)

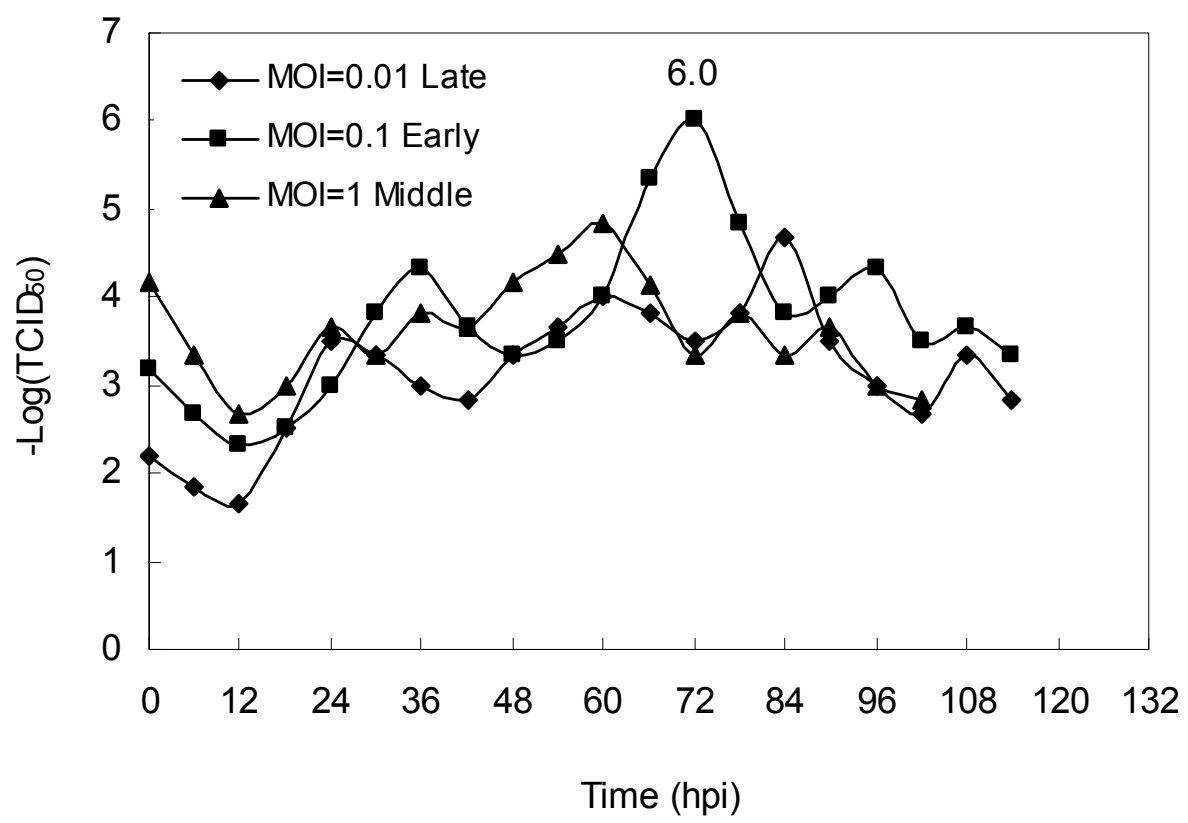

(b) 


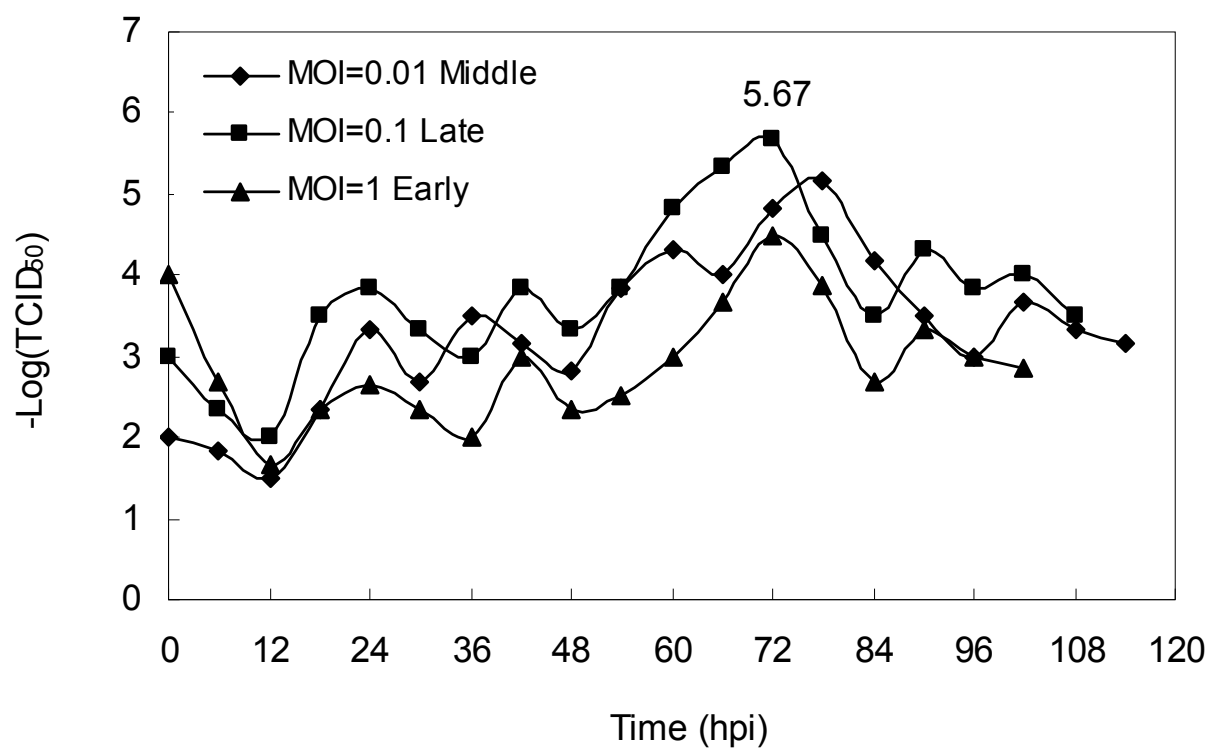

(c)

Fig. 2. Evolution of the minus logarithm of the TCID 50 for the ICDs of $1.0 \times 10^{5}$ cells $\mathrm{mL}^{-1}(\mathrm{a})$, $2.0 \times 10^{5}$ cells mL-1 (b) and $3.0 \times 10^{5}$ cells $\mathrm{mL}^{-1}(\mathrm{c})$. The errors of all the sample analyses ranged from $0 \%$ to $5 \%$ and are not indicated in the panels.

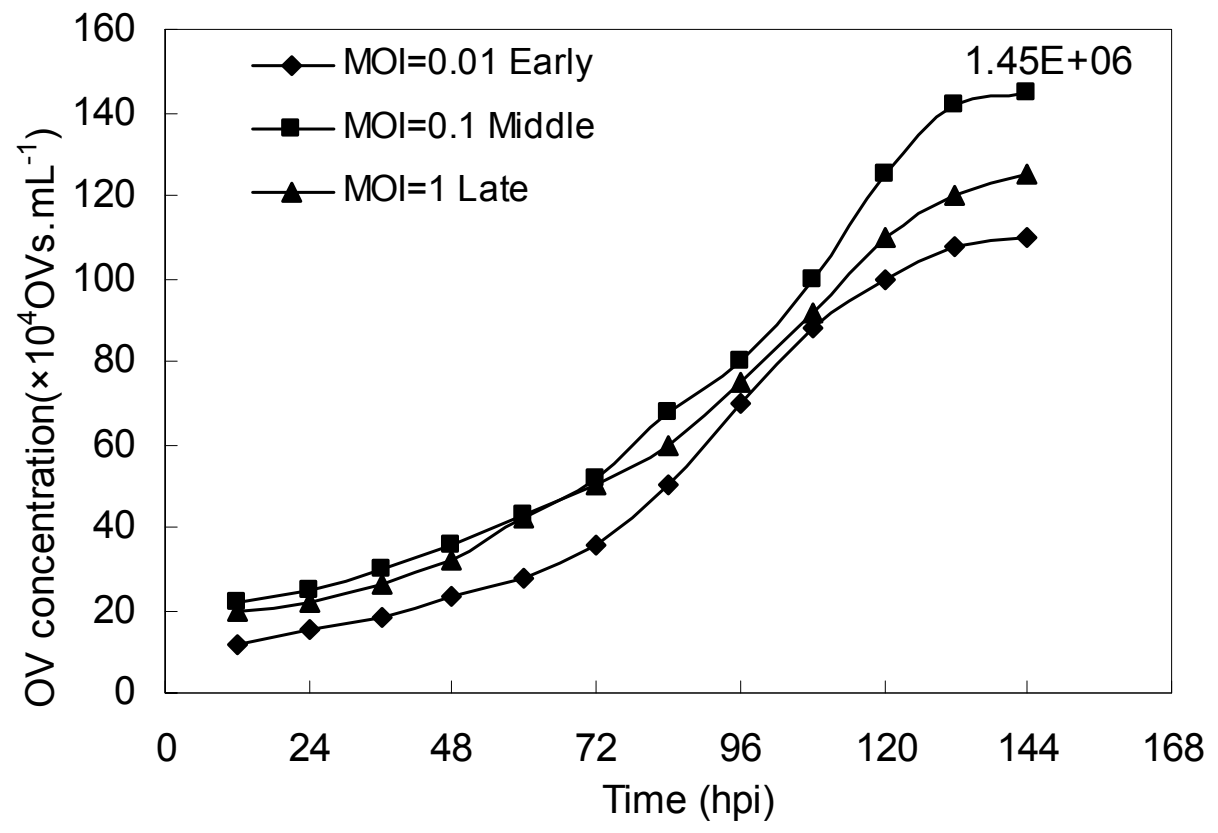

(a) 


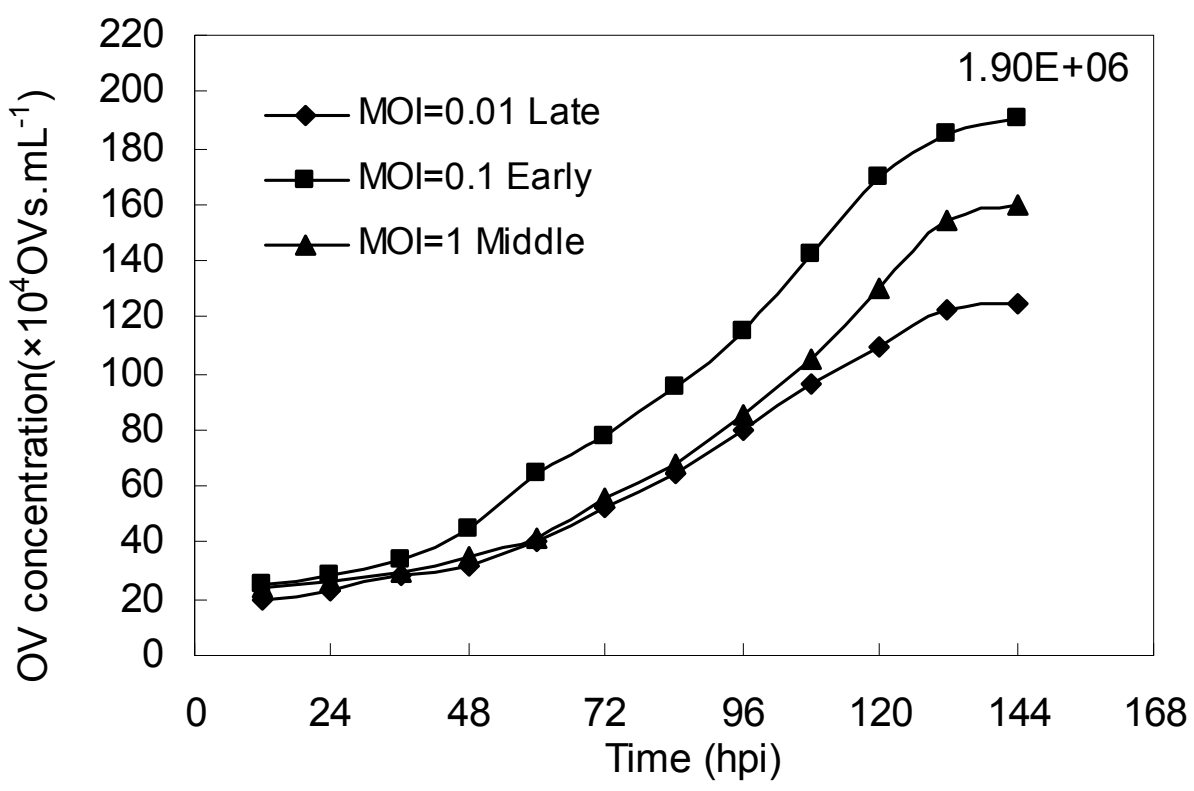

(b)

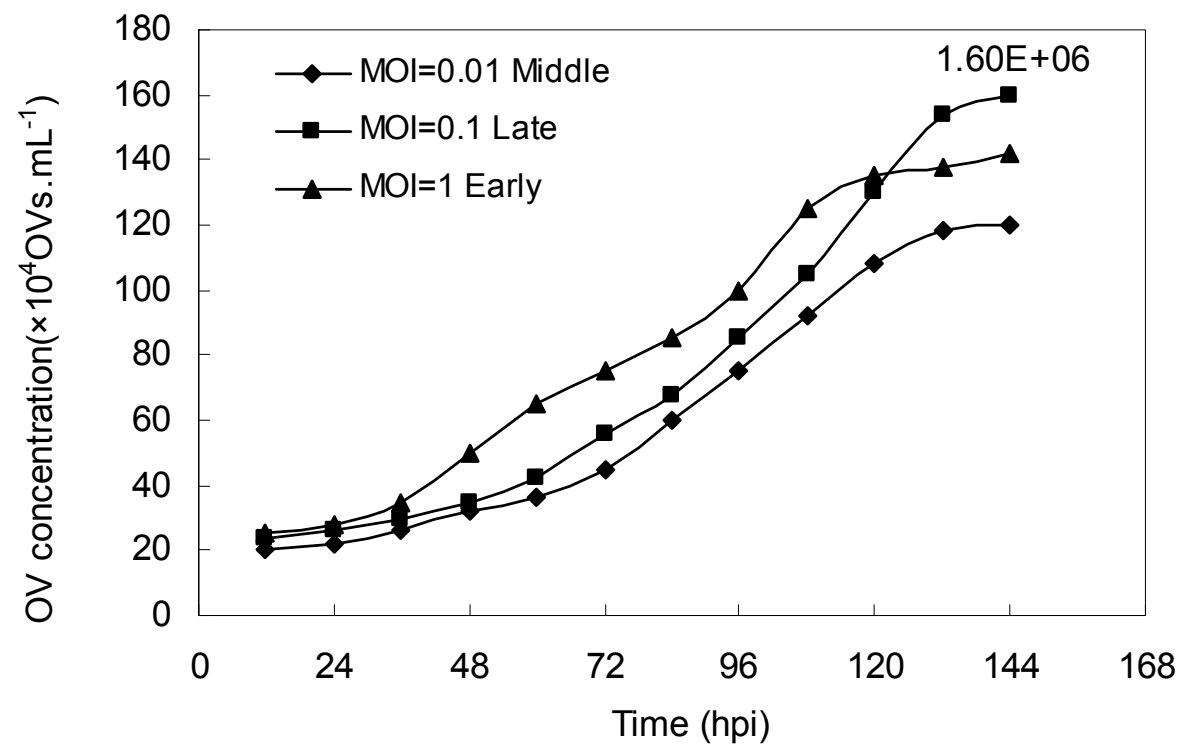

(c)

Fig. 3. Evolution of the amount of OVs for the ICDs of $1.0 \times 10^{5}$ cells $\mathrm{mL}^{-1}$ (a), $2.0 \times 10^{5}$ cells $\mathrm{mL}^{-1}(\mathrm{~b})$ and $3.0 \times 10^{5}$ cells $\mathrm{mL}^{-1}(\mathrm{c})$. The errors of all the sample analyses ranged from $0 \%$ to $5 \%$ and are not indicated in the panels. 


\section{Discussion}

\subsection{Optimization of the MOI for BV and OV productions}

The effects of the MOI on the BV titer and OV concentration at three different levels as factor A are shown in Tables 2 and 3. It can be seen from Table 2 that the $K m(m=1-3)$ values corresponding to the MOIs were $1.309 \times 10^{6}, 1.0427 \times 10^{7}$ and $8.65 \times 10^{5} \mathrm{TCID}_{50} \mathrm{~mL}^{-1}$, which represent the average $\mathrm{BV}$ response values at the three MOIs of 1.0, 0.10 and 0.01 , respectively, and reflect the effects of the MOI on BV production. The maximum value, $K_{2}$, was $1.0427 \times 10^{7} \mathrm{TCID}_{50} \mathrm{~mL}^{-1}$ at a MOI of 0.10 . The difference between the maximum value $K_{2}$ and the minimum value $K_{3}$, i.e., the $\mathrm{R}$ value corresponding to the MOI, was $9.56 \times 10^{6} \mathrm{TCID}_{50}$ $\mathrm{mL}^{-1}$, which is higher than the other $\mathrm{R}$ values of $6.48 \times 10^{6}$ and $4.90 \times 10^{6} \mathrm{TCID}_{50} \mathrm{~mL}^{-1}$ corresponding to the ICD and TOI, respectively. These findings indicate that the sensitivity of the MOI to the BV titer is highest when a low MOI is used. In the same way, it can be seen from Table 3 that the $\mathrm{Km}^{\prime}(\mathrm{m}=1-3)$ values corresponding to the MOIs were $1.18 \times 10^{6}, 1.65 \times 10^{6}$ and $1.42 \times 10^{6} \mathrm{OVs} \mathrm{mL}^{-1}$, which represent the average OV response values at the three MOIs of 1.0, 0.10 and 0.01 , respectively, and reflect the effects of the MOI on OV production. The maximum value, $K_{2}{ }^{\prime}$, i.e., the optimal condition, was achieved at a MOI of 0.10 , indicating that the optimal MOI for OV production was the same as that for BV production. The difference between the maximum value $K_{2}{ }^{\prime}$ and the minimum value $K_{1}$ ', i.e., the $R^{\prime}$ value corresponding to the MOI, was $4.7 \times 10^{5} \mathrm{OVs} \mathrm{mL}^{-1}$, which is higher than the other $\mathrm{R}$ values of $3.2 \times 10^{5}$ and $1.1 \times 10^{5} \mathrm{OVs} \mathrm{mL}^{-1}$ corresponding to the ICD and TOI, respectively. These findings indicate that the sensitivity of the MOI to the OV concentration is highest when a low MOI is used. Therefore, it is concluded that the MOI has relatively significant influences on the BV titer and OV concentration when a low MOI is used. Furthermore, it can be seen from the data for the 9 experiments shown in the last columns of Tables 2 and 3 that both the maximum $\mathrm{BV}$ titer and maximum $\mathrm{OV}$ concentration were produced at $\mathrm{A}_{2}$, i.e., a MOI of 0.10 .

\subsection{Optimization of the ICD for BV and OV productions}

The effects of the ICD on the BV titer and OV concentration at three different levels as factor $\mathrm{B}$ are shown in Tables 2 and 3. It can be seen from Table 2 that the $K m(m=1-3)$ values corresponding to the ICDs were $9.44 \times 10^{5}, 4.24 \times 10^{6}$ and $7.42 \times 10^{6} \mathrm{TCID}_{50} \mathrm{~mL}^{-1}$, which represent the average BV response values at the three levels of ICD, respectively, and reflect the effects of the ICD on BV production. The maximum value, $K_{3}$, was $7.419 \times 10^{6} \mathrm{TCID}_{50} \mathrm{~mL}^{-}$ 1 at the ICD of $2.0 \times 10^{5}$ cells $\mathrm{mL}^{-1}$. The difference between the maximum value $K_{3}$ and the minimum value $K_{1}$, i.e., the $\mathrm{R}$ value corresponding to the ICD, was $6.48 \times 10^{6} \mathrm{TCID}_{50} \mathrm{~mL}^{-1}$, which is higher than $4.90 \times 10^{6} \mathrm{TCID}_{50} \mathrm{~mL}^{-1}$ corresponding to the TOI, but smaller than $9.56 \times 10^{6} \mathrm{TCID}_{50} \mathrm{~mL}^{-1}$ corresponding to the MOI. These findings indicated that the sensitivity of the ICD to the BV titer is not high (as described above). In addition, it can be seen from Table 3 that the $\mathrm{Km}^{\prime}(\mathrm{m}=1-3)$ values corresponding to the ICDs were $1.27 \times 10^{6}, 1.41 \times 10^{6}$ and $1.58 \times 10^{6} \mathrm{OVs} \mathrm{mL}^{-1}$, which represent the average OV response values at the three levels of ICD, respectively, and reflect the effects of the ICD on OV production. The maximum value, $K_{3}{ }^{\prime}$, i.e., the optimal condition, was achieved at an ICD of $2.0 \times 10^{5}$ cells $\mathrm{mL}^{-1}$, indicating that the optimal ICD for OV production was the same as that for BV production. Furthermore, it can be seen from the data for the nine experiments shown in the last columns of Tables 2 and 3 that both the maximum BV titer and maximum OV concentration were produced at $B_{3}$, i.e., an ICD of $2.0 \times 10^{5}$ cells $\mathrm{mL}^{-1}$. 


\subsection{Optimization of the TOI for BV and OV productions}

The effects of the TOI on the BV titer and OV concentration at three different levels as factor $\mathrm{C}$ are shown in Tables 2 and 3. It can be seen from Table 2 that the $K m(m=1-3)$ values corresponding to the TOIs were $6.94 \times 10^{6}, 2.04 \times 10^{6}$ and $3.61 \times 10^{6} \mathrm{TCID}_{50} \mathrm{~mL}^{-1}$, which represent the average $\mathrm{BV}$ response values at the three levels of TOI, respectively, and reflect the effects of the TOI on BV production. The maximum value, $K_{1}$, was $6.94 \times 10^{6} \mathrm{TCID}_{50} \mathrm{~mL}^{-1}$ at the early exponential phase. The difference between the maximum value $K_{1}$ and the minimum value $K_{2}$, i.e., the $\mathrm{R}$ value corresponding to the TOI, was $4.9 \times 10^{6} \mathrm{TCID}_{50} \mathrm{~mL}^{-1}$, which is the smallest among the three $\mathrm{R}$ values (as described above), indicating that the TOI has a weak influence on BV production when a low MOI is used. In addition, it can be seen from Table 3 that the $\mathrm{Km}^{\prime}(\mathrm{m}=1-3)$ values corresponding to the TOIs were $1.47 \times 10^{6}, 1.42 \times 10^{6}$ and $1.37 \times 10^{6} \mathrm{OVs} \mathrm{mL}^{-1}$, which represent the average OV response values at the three TOIs, respectively, and reflect the effects of the TOI on OV production. The maximum value, $K_{1}{ }^{\prime}$, i.e., the optimal condition, was achieved at the early exponential phase, indicating that the optimal TOI for OV production was the same as that for BV production. Furthermore, it can be seen from the data for the 9 experiments shown in the last columns of Tables 2 and 3 that both the maximum $\mathrm{BV}$ titer and maximum $\mathrm{OV}$ concentration were produced at $\mathrm{C}_{1}$, i.e., at the early exponential phase.

\subsection{Effects of the MOI, ICD and TOI on BV and OV productions}

The effects of the MOI, ICD and TOI on BV and OV productions can be seen from the R and $R^{\prime}$ values (Tables 2 and 3), which were used to evaluate the sensitivity of each variable to the $\mathrm{BV}$ titer or OV concentration. The $\mathrm{R}$ values corresponding to the MOI, ICD and TOI were $9.56 \times 10^{6}, 6.48 \times 10^{6}$ and $4.90 \times 10^{6} \mathrm{TCID}_{50} \mathrm{~mL}^{-1}$, respectively, indicating that the MOI has the most significant influence on BV production, followed by the ICD and finally the TOI in the HzAM1 cell-recombinant baculovirus system when a low MOI is used. Furthermore, the $\mathrm{R}^{\prime}$ values corresponding to the MOI, ICD and TOI were $4.7 \times 10^{5}, 3.2 \times 10^{5}$ and $1.1 \times 10^{5} \mathrm{OVs} \mathrm{mL}^{-1}$, respectively, demonstrating similar effects of the MOI, ICD and TOI on OV production compared with BV production. As stated above, the optimal conditions for both BV production and OV production in the HzAM1 cell-recombinant baculovirus system were a MOI of 0.10 , an ICD of $2.0 \times 10^{5}$ cell mL-1 and a TOI at the early exponential phase.

With respect to the MOIs of 1.0, 0.10 and 0.01 , most of the HzAM1 cells were likely to be infected at a MOI of 1.0 at the early exponential phase because more viruses were added to the culture compared with the MOIs of 0.10 and 0.01 , and as a result, there were insufficient uninfected cells to propagate for infection at later time points with viruses generated during the 'primary infection process' (Kioukia et al., 1995; Zhang et al., 2005). As shown in Fig. 1c, the unstained cell concentration showed a sharp decrease at $72 \mathrm{~h}$ after the inoculation when the cells were infected at a MOI of 1.0 at 24 h, i.e., the early exponential phase. Therefore, the numbers of BVs and OVs produced would exhibit lesser increases in the secondary and tertiary infections when a MOI of 1.0 was used at the early exponential phase as shown in Figs. $2 c$ and 3c. Conversely, if the HzAM1 cells were infected at a MOI of 0.01 at the early exponential phase, fewer cells would be infected and the number of viruses generated in the primary infection process would be lower. It is possible that most of the uninfected cells and their progeny would not be infected before the cells entered into the stationary phase or death phase as shown in Fig. 1a, indicating that these cells would not play a role in virus replication because of their weak physiological state. Therefore, the maximum BV and OV productions were not obtained when the cells were infected at MOIs of 0.01 (Figs. 2a and 3a) and 1.0 (Figs. 
$2 c$ and $3 c$ ) at the early exponential phase. However, the number of cells infected was likely to be suitable for later infection cycles when the MOI was 0.1 , which resulted in the maximum productions of BVs (Fig. 2a-c) and OVs (Fig. 3a-c). The evolution of unstained cells (Fig. 1) and the dynamics of BVs (Fig. 2) and OVs (Fig. 3) at a MOI of 0.1 were very complicated and similar to those in our previous studies (Enden et al., 2005; Zhang et al., 2005), and are thus not elaborated upon in this paper. With respect to the three ICDs, when the ICD was $1 \times 10^{5}$ cells $\mathrm{mL}^{-1}$, the remaining uninfected cells would be too few to propagate for infection in later infection cycles compared with the ICDs of $2 \times 10^{5}$ and $3 \times 10^{5}$ cells $\mathrm{mL}^{-1}$. However, when the ICD was $3 \times 10^{5}$ cells $\mathrm{mL}^{-1}$, the remaining uninfected cells would be too many to propagate for infection in later infection cycles compared with the ICDs of $1 \times 10^{5}$ and $2 \times 10^{5}$ cells $\mathrm{mL}^{-1}$. These extra cells would be likely to proliferate vigorously in the early exponential phase, and as a result, the nutrient components in the culture would be consumed too early and too rapidly for subsequent infection cycles. This means that the physiological environment in the culture would deteriorate and have no benefit for the uninfected cells and their progeny to be infected with BVs during the later infection process. Therefore, the cells at the ICDs of $1 \times 10^{5}$ cells $\mathrm{mL}^{-1}$ (see Figs. 2a and 3a) and $3 \times 10^{5}$ cells $\mathrm{mL}^{-1}$ (see Figs. $2 \mathrm{c}$ and $3 \mathrm{c}$ ) infected at a MOI of 0.1 would not reach the maximum amounts of BVs and OVs, whereas the cells infected at an ICD of $2 \times 10^{5}$ cells $\mathrm{mL}^{-1}$ would reach the maximum amounts of BVs and OVs (see Figs. $2 \mathrm{~b}$ and $3 \mathrm{~b}$ ). With respect to the TOI (early, middle or late exponential growth phase), the cells infected at a low MOI at the early exponential growth phase achieved a longer period of culture with the added viruses and their progeny viruses (BVs) to create more infection cycles before the cells entered the stationary phase or death phase compared with the cells infected at the middle and late exponential growth phases. This is probably an important reason why better effects on the amounts of BV and OV productions were observed when infection was carried out at the early exponential growth phase (see Figs. $2 \mathrm{~b}$ and $3 b$ ). The interplay among the MOI, TOI and ICD in the HzAM1 cell-recombinant baculovirus system has not been understood at the theoretical level. Currently, our research is focusing on the relationships of the cell cycle phases and cell cycle distributions with virus infection using a synchronization method and flow cytometry, with further attempts to understand the relationships between the amounts of viruses produced and the cell states when infected.

In conclusion, to avoid the complexity of the technology associated with large scale production, high MOIs and medium replacement were not considered as factors to be investigated in our studies. An orthogonal design was applied to select the optimum conditions, in which the effects of the MOI, ICD and TOI on the productions of BVs and OVs were evaluated in the HzAM1 cell-recombinant baculovirus system. The results indicated that among the MOI, TOI and ICD, the MOI had relatively significant influences on the amounts of $\mathrm{BVs}$ and OVs produced at a low MOI. The optimal conditions for both BV and OV productions in the HzAM1 cell-recombinant baculovirus system were a MOI of 0.10 , an ICD of $2.0 \times 10^{5}$ cells $\mathrm{mL}^{-1}$ and a TOI at the early exponential phase. These findings are logically reasonable and indicate that $\mathrm{BVs}$ and OVs are closely related, representing only two different virion phenotypes. Virus titers as high as $2.0 \times 10^{7} \mathrm{TCID}_{50} \mathrm{~mL}^{-1}$, equivalent to $9.2 \times 10^{9} \mathrm{IPs} \mathrm{mL}^{-1}$, were obtained without medium replacement at a low MOI, which represent the best results obtained for the HzAM1 cell-recombinant baculovirus system, based on comparisons with previously reported data (McIntosh et al., 2001; Wang et al., 2008). Overall, the present data demonstrate that high titers can be obtained at a low MOI and that the technology required for this bioprocess was shortened by an efficient orthogonal design. Furthermore, the interplay among the MOI, TOI and ICD was elucidated. 


\section{Acknowledgments}

The authors are grateful to Dr. Hualin Wang of the Wuhan Institute of Virology, Chinese Academy of Sciences, for providing the HzAM1 cells and HaBacHZ8-eGPF-PH. This work was supported by the National Nature Science Foundations of China (20876120) and the Wuhan Municipal Fund of Science and Technology of China (20052002044).

\section{References}

Atkinson, A.E.; Weitzman, M.D.; Obosi, L.; Beadle, D.J. \& King, L.A. (1990). Baculovirus as vectors for foreign gene expression in insect cells. Pesticide. Sci. Vol. 28, No. 2, (August 1989), pp. 215-224, ISSN 0031-613X

Blissard, G.W. (1996). Baculovirus-insect cell interactions. Cytotechnology: International Journal of Cell culture and Biology,, Vol. 20, (1996), pp. 73-93, ISSN 0920-9069

Bonning, B.C. \& Hammock, B.D. (1992). Development and potential of genetically engineered viral insecticides. Biotechnology and genetic engineering reviews, Vol. 10, (1992), pp. 455-489, ISSN 026-8725

Carinhas, N.; Bernal, V.; Yokomizo, A.Y.; Carrondo, M.J.; Oliveira, R. \& Alves, P.M. (2009). Baculovirus production for gene therapy: the role of cell density, multiplicity of infection and medium exchange. Appl. Microbiol. Biotechnol. Vol. 81, No. 6, (October 2008), pp. 1041-1049, ISSN 0175-7598

Caron, A.W.; Archambault, J. \& Massie, B. (1990). High-level recombinant protein production in bioreactors using the baculovirus-insect cell expression system. Biotechnol. Bioeng. Vol. 36, No. 11, (December 1990) pp. 1133-1140, ISSN 0006-3592

Cha, H.J.; Gotoh, T. \& Bentley, W.E. (1997). Simplification of titer determination for recombinant baculovirus by green fluorescent protein marker. Biotechniques Vol. 23, No. 5, (1997), pp. 782-786, ISSN 0736-6205

Davies, A.H. (1994). Current methods for manipulating baculoviruses. Bio/Technology. Vol. 12, (1994), pp. 47-50, ISSN 1087-0156

de Gooijer, C.D.; van Lier, F.L.J.; van den End, E.J.; Vlak, J.M. \& Tramper, J. (1989). A model for baculovirus production with continuous insect cell cultures. Appl. Microbiol. Biotechnol. Vol. 30, No. 5, (1989), pp. 497-501, ISSN 0175-7598

de Gooijer, C.D.; Koken, R.H.M.; van Lier, F.L.J.; Kool, M.; Vlak, J.M. \& Tramper, J. (1992). A structured dynamic model for the baculovirus infection process in insect-cell reactor configuration. Biotechnol. Bioeng. Vol. 40, No. 4, (August 1992), pp. 537-548, ISSN 0006-3592

Enden, G.; Zhang, Y.H. \& Merchuk, J.C. (2005). A model of the dynamics of insect cell infection at low multiplicity of infection. J. Theor. Biol. Vol. 237, No. 3, (December 2005), pp. 257-264, ISSN 0022-5193

Ernst, W.J.; Grabherr, R.M. \& Katinger, H.W.D. (1994). Direct cloning into the Autographa californica nuclear polyhedrosis virus for generation of recombinant baculoviruses. Nuclei Acids Res. Vol. 22, No. 14, (1994), pp. 2855-2856, ISSN 0305-1048

Gotoh, T.K.; Miyazaki, Y.H.; Chiba, K.H. \& Kikuchi, K.I. (2002). Significant increase in recombinant protein production of a virus-infected Sf-9 insect cell culture of low MOI under low dissolved oxygen conditions. J. Biosci. Bioeng. Vol. 94, No. 5, (August 2002), pp. 426-433, ISSN 1389-1723

Hirumi, H.; Hirumi, K. \& Mclntosh, A.H. (1975). Mrophogenesis of a nuclear polyhedrosis virus of the alfafa looper in a continuous cabbage looper cell line. Ann. N.Y. Acad. Sci. Vol. 226, (November 1975), pp. 302-326, ISSN 0077-8923 
$\mathrm{Hu}$, Y.C. \& Bentley, W.E. (2001). Effect of MOI ratio on the composition and yield of chimeric infectious bursal disease virus-like particles by baculovirus co-infection: deterministic predictions and experimental results. Biotechnol. Bioeng. Vol. 75, No. 1, (October 2001), pp. 104-109, ISSN 0006-3592

Ignoffo, C.M. (1968). Specificity of insect viruses. Bull. Entomol. Soc. Am. Vol. 14, No. 4, (1968), pp. 265-276, ISSN 0013-8754

Jing, T.; Li, X.; Song, J.H.; Ling, C.Y. \& Chen, X.W. (2008). Baculovirus per os infectivity factors are involved in HearNPV ODVs infection of HzAM1 cells in vitro. Virol. Sin. Vol. 23, No. 1, (February 2008), pp. 25-30, ISSN 1674-0769

Jones, K.A. 1994. Use of baculovirus for cotton pest control. In Insect pests of cotton (Matthews, G.A.; Tunstall, J.P., eds), CAB International, Wallingford, UK, ( November 1994) pp. 477-504, ISBN 0-85198-724-9

Keddie, G.A.; Aponte, G.W. \& Volkman, L.E. (1989). The pathway of infection of Autographa californica nuclear polyhedrosis virus in an insect host. Science Vol. 243, No. 4899, (March 1989), pp. 1728-1730, ISSN 0036-8075

Kitts, P.A. (1996). Construction of baculovirus recombinants. In: Vlak, J.M.; de Gooijer, C.D.; Tramper, J. \& Miltenburger, H.G. (eds) International journal of cell culture and biology: cytotechnology. Vol. 20 (pp. 111-123) Kluwer Academic Publishers, Netherlands.

Kioukia, N.; Nienow, A.W.; Emery, A.N. \& AI-Rubeai, M. (1995). Physiological and environmental factors affecting the growth of insect cells and infection with baculovirus. J. Biotechnol. Vol. 38, (October 1994), pp. 243-251, ISSN 0168-1656

Knudon, D.L. \& Harrap, K.A. (1976). Replication of a nuclear polyhedrosis virus in a continuous cell culture of Spodoptera frugiperda: microscopy study of the sequence of events of the virus infectiion. J. Virol. Vol. 17, No. 1, (January 1976), pp. 254-268, ISSN 0022-538X

Kumar, A. \& Shuer, M.L. (1995). Model of a split-flow airlift bioreactor for attachmentdependent, baculovirus-infected insect cells. Biotechnol. Prog. Vol. 11, No. 4, (August 1995), pp. 412-419, ISSN 1520-6033

Maranga, L.; Brazao, T.F. \& Carrondo, M.J.T. (2003). Virus-like particle production at low multiplicities of infection with the baculovirus insect cell system. Biotech. Bioeng. Vol. 84, (October 2003), pp. 245-253, ISSN 0006-3592

Mariorella, B.; Inlow, D.; Shauger, A. \& Harano, D. (1988). Large scale insect cell culture for recombinant production. Biotechnology Vol. 6, (1988), pp. 1406-1410, ISSN 1087-0156

McIntosh, A.H.; Grasela, J.J.; Goodman, C.L. \& Ignoffo, C.M. (2001). Growth of a clonal cell line of Helicoverpa zea (Lepidoptera: Noctuidae) in suspension culture and replication of its homologous baculovirus HzSNPV. Appl. Entomol. Zool. Vol. 36, (April 2001), pp. 349-352, ISSN 0003-6862

Nielsen, L.K.; Smyth, C.K. \& Greenfield, P.F. (1992). Accuracy of the endpoint assay for virus titration. Cytotechnology Vol. 8, No. 3, (1992), pp.231-236, ISSN 0920-9069

Pan, X.Y.; Long, G.; Wang, R.R.; Hou, S.W.; Wang, H.Y.; Zheng, Y.T.; Sun, X.L.; Westenberg, M.; Deng, F.; Wang, H.L.; Vlak, J.M. \& Hu Z. (2007). Deletion of a Helicoverpa armigera nucleopolyhedrovirus gene encoding a virion structural protein (ORF107) increases the budded virion titre and reduces in vivo infectivity. J. Gen. Virol. Vol. 88, (2007), pp. 3307-3316, ISSN 0022-1317

Power, J.F.; Reid, S.; Greenfield, P.F. \& Nielsen, L.K. (1996). The kinetics of baculovirus adsorption to insect cells in suspension culture. Cytotechnology Vol. 21, No. 2, (1996), pp. 155-163, ISSN 0920-9069

Primentel, D. \& Andow, D. (1980). Environmental and social costs of pesticides: a preliiminary assessment. OIKOS. Vol. 34, No. 2, (1980), pp. 126-140, ISSN 1600-0706 
Radford, K.M.; Cavegn, C.; Bertrand, M.; Bernard, A.R.; Reid, S. \& Greenfield, P.F. (1997). The indirect effects of multiplicity of infection on baculovirus expressed proteins in insect cells: secreted and non-secreted products. Cytotechnology Vol. 24, No. 1, (1997), pp. 73-81, ISSN 0920-9069

Raghow, R. \& Grace, T.D. (1974). Studies on a nuclear polyhedrosis virus in Bombyx mori cells in vitro I. Multiplication kinetics and ultrastructural studies. J. Ultrastruct. Res. Vol. 47, No. 3, (1974), pp. 384-399, ISSN 0022-5320

Reed, L. \& Muench, H. (1938). A simple method for estimating fifty percent endpoints. Am. J. Epidemiol. Vol. 27, No. 3, (May 1938), pp. 493-497, ISSN 0002-9262

Rice, J.W.; Rankl, N.B.; Gurganus, T.M.; Marr, C.M.; Barna, J.B.; Waiters, M.M. \& Burns, D.J. (1993). A comparison of large-scale Sf 9 insect cell growth and protein production: stirred vessel vs airlift. Biotechniques. Vol. 15, No. 6, (1993), pp. 1952-1959, ISSN 0736-6205

Rodas, V.M.; Marques, F.H.; Honda, M.T.; Soares, D.M.; Jorge, S.A.C.; Antoniazzi, M.M.; Medugno, C.; Castro, M.E.B.; Ribeiro, B.M.; Souza, M.L.; Tonso, A. \& Pereira, C.A. (2005). Cell culture derived AgMNPV bioinsecticide: biological constraints and bioprocess issues. Cytotechnology Vol. 48, No. 1-3, (2005), pp. 27-39, ISSN 0920-9069

Shieh, T.R. 1989. Industrial production of viral pesticides. Adv. Virus Res. Vol. 36, (1989) pp. 315-343, ISSN 0065-3527

Volkman, L.E.; Summers, M.D. \& Hsieh, C.H. (1976). Occluded and nonoccluded nuclear polyhedrosis virus grown in Trichoplusia ni: neutralization, comparativve infectivity, and in vitro grown studies. J. Virol. Vol. 19, No. 3, (September 1976), pp. 820-832, ISSN 0022-538X

Wang, M.L.; Tan, Y.; Yin, F.F.; Deng, F.; Vlak, J.M.; Hu, Z.H. \& Wang, H.L. (2008). The F protein of Helicoverpa armigera single nucleopolyhedrovirus can be substituted functionally with its homologue from Spodoptera exigua multiple nucleopolyhedrovirus. J. Gen. Virol. Vol. 89, (2008), pp. 791-798, ISSN 0022-1317

Wickham, T.J.; Nemerow, G.R.; Wood, H.A. \& Shuler M.L. (1995). Comparison of different cell lines for the production of recombinant baculovirus proteins. Methods Mol. Biol. Vol. 39, (1995), pp. 385-395, ISSN 1064-3746

Wong, K.T.K.; Peter, C.H.; Greenfield, P.F.; Reid, S. \& Nielsen, L.K. (1996). Low multiplicity infection of insect cells with a recombinant baculovirus: The cell yield concept. Biotechnol. Bioeng. Vol. 49, No. 6, (March 1996), pp. 659-666, ISSN 1097-0290

Wood, H.A. \& Granados, R.R. (1991). Genetically engineered baculoviruses as agents for pest control. Ann. Rev. Microbiol. Vol. 45, (October 1991), pp. 69-87, ISSN 0066-4227

Yamaji, H.K.; Tagai, S.I. \& Fukuda, H.K. (1999). Optimal production of recombinant protein by the baculovirus-insect cell system in shake-flask culture with medium replacement. J. Biosci. Bioeng. Vol. 87, No. 5, (January 1999), pp. 636-641, ISSN 1389-1723

Zhang, J.; Kalogerakis, N.; Behie, L.A. \& Iatrou K. (1993). A two-stage bioreactor system for the production of recombinant proteins using a genetically engineered baculovirus/ insect cell system. Biotechnol. Bioeng. Vol. 42, (July 1993), pp. 357-366, ISSN 1097-0290

Zhang, G.Y. 1989. Commercial viral insecticide-Heliothis armigera viral insecticide in China. The IPM Practitioner Vol. 11, (1989) pp. 13

Zhang, G.Y.; Sun, X.L.; Zhang, Z.X.; Zhang, Z.F. \& Wan, F.F. 1995. Production and effectiveness of the new formulation of Helicoverpa virus pesticide-emulsifiable suspension. Virologica Sinica Vol. 10, (1995) pp. 242-247, ISSN 1674-0769

Zhang, Y.H.; Enden, G. \& Merchuk, J.C. (2005). Insect cells-baculovirus system: Factors affecting growth and low MOI infection. Biochem. Eng. J. Vol. 27, No. 1, (December 2005), pp. 8-16, ISSN 1369-703X 


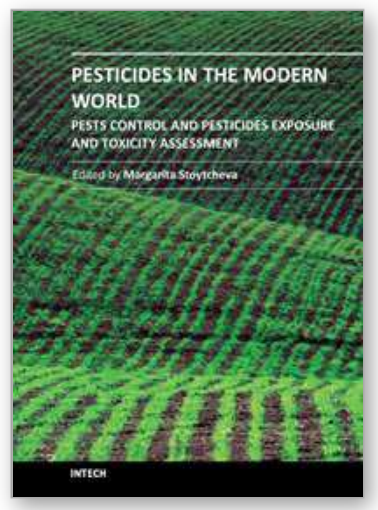

\section{Pesticides in the Modern World - Pests Control and Pesticides Exposure and Toxicity Assessment}

Edited by Dr. Margarita Stoytcheva

ISBN 978-953-307-457-3

Hard cover, 614 pages

Publisher InTech

Published online 30, September, 2011

Published in print edition September, 2011

The present book is a collection of selected original research articles and reviews providing adequate and upto-date information related to pesticides control, assessment, and toxicity. The first section covers a large spectrum of issues associated with the ecological, molecular, and biotechnological approaches to the understanding of the biological control, the mechanism of the biocontrol agents action, and the related effects. Second section provides recent information on biomarkers currently used to evaluate pesticide exposure, effects, and genetic susceptibility of a number of organisms. Some antioxidant enzymes and vitamins as biochemical markers for pesticide toxicity are examined. The inhibition of the cholinesterases as a specific biomarker for organophosphate and carbamate pesticides is commented, too. The third book section addresses to a variety of pesticides toxic effects and related issues including: the molecular mechanisms involved in pesticides-induced toxicity, fish histopathological, physiological, and DNA changes provoked by pesticides exposure, anticoagulant rodenticides mode of action, the potential of the cholinesterase inhibiting organophosphorus and carbamate pesticides, the effects of pesticides on bumblebee, spiders and scorpions, the metabolic fate of the pesticide-derived aromatic amines, etc.

\section{How to reference}

In order to correctly reference this scholarly work, feel free to copy and paste the following:

Guohong Zhou, Youhong Zhang and Yujie Ke (2011). Optimization of the Strategy for Recombinant Baculovirus Infection of Suspended Insect Cells, Pesticides in the Modern World - Pests Control and Pesticides Exposure and Toxicity Assessment, Dr. Margarita Stoytcheva (Ed.), ISBN: 978-953-307-457-3, InTech, Available from: http://www.intechopen.com/books/pesticides-in-the-modern-world-pests-control-andpesticides-exposure-and-toxicity-assessment/optimization-of-the-strategy-for-recombinant-baculovirusinfection-of-suspended-insect-cells

\section{INTECH}

open science | open minds

\section{InTech Europe}

University Campus STeP Ri

Slavka Krautzeka 83/A

51000 Rijeka, Croatia

Phone: +385 (51) 770447

Fax: +385 (51) 686166

\section{InTech China}

Unit 405, Office Block, Hotel Equatorial Shanghai

No.65, Yan An Road (West), Shanghai, 200040, China 中国上海市延安西路65号上海国际贵都大饭店办公楼 405 单元

Phone: +86-21-62489820

Fax: +86-21-62489821 
www.intechopen.com 
(C) 2011 The Author(s). Licensee IntechOpen. This chapter is distributed under the terms of the Creative Commons Attribution-NonCommercialShareAlike-3.0 License, which permits use, distribution and reproduction for non-commercial purposes, provided the original is properly cited and derivative works building on this content are distributed under the same license. 